\title{
PEMANFAATAN KITOSAN DAN JAMUR LAPUK PUTIH (Trametes versicolor) UNTUK MENURUNKAN KEKERUHAN DAN WARNA PADA AIR GAMBUT SEBAGAI SUMBER AIR BERSIH ALTERNATIF
}

\author{
Karelius \\ Program Studi Pendidikan Kimia \\ Jurusan Pendidikan MIPA Fakultas Keguruan dan Ilmu Pendidikan \\ Universitas Palangka Raya \\ e-mail : iwanherman57@yahoo.com
}

\begin{abstract}
ABSTRAK
Telah dilakukan penelitian tentang pemanfaatan kitosan dan jamur lapuk putih (trametes versicolor) untuk menurunkan kekeruhan dan warna pada air gambut sebagai sumber air bersih alternatif dengan tujuan adalah mengetahui perbandingan dosis optimum kitosan dan jamur lapuk serta mempelajari kondisi optimum proses koagulasi dan flokulasi yaitu pengaruh waktu pengadukan dengan kecepatan $40 \mathrm{rpm}$ dan pengendapan terhadap penurunan kekeruhan dan warna pada air gambut.

Kitosan yang akan digunakan diisolasi dari limbah kulit udang yang dibuat melalui tiga tahap yakni tahap deproteinasi, demineralisasi dan deasetilasi. Penentuan dosis optimum dilakukan dengan variasi dosis kitosan dan jamur lapuk putih perbandingan 800 : 200; $600: 400 ; 400: 600 ; 500: 500$ dan $200: 800$ (mg/L air gambut). Pengaruh waktu pengadukan lambat terhadap efektifitas koagulasi dan flokulasi dipelajari dengan cara koagulasi dilakukan pada waktu bervariasi yaitu selama 5, 10, 15, 20 dan 25 menit. Pengaruh waktu pengendapan dipelajari dengan suspensi hasil koagulasi diendapkan dengan waktu yang bervariasi selama 15, 30, 45, 60 dan 90 menit. Setelah diketahui dosis dan kondisi optimum koagulasi dan flokulasi selanjutnya diaplikasikan pada 3 (tiga) sampel air gambut yang diperoleh dari 3 (tiga) lokasi yang berbeda.

Perbandingan dosis optimum kitosan dan jamur lapuk putih parameter kekeruhan adalah 600 : $400 \mathrm{mg} / \mathrm{L}$ air gambut dengan efektifitas sebesar 95,06\%, dan parameter warna dengan perbandingan dosis optimum $400: 600 \mathrm{mg} / \mathrm{L}$ air gambut dengan efektifitas 96,20\%. Waktu pengadukan dengan kecepatan 40 rpm optimum adalah 10 menit untuk parameter kekeruhan dan warna air gambut, dengan efektifitas masing-masing $\quad 96,34 \%$ dan 96,68 \%. Waktu pengendapan yang optimum adalah pada waktu 45 menit untuk parameter kekeruhan dan 60 menit untuk parameter warna air gambut, dengan efektifitas masing-masing 96,37\% dan 96,68\%. Aplikasi kitosan dan jamur lapuk putih pada air gambut, KLP 1 dan KLP 2 dapat dikatakan layak untuk digunakan sebagai sumber air bersih, dengan tingkat kekeruhan dan intensitas warna masing-masing adalah 1,27 NTU; 2,90 NTU dan 6,30 Pt-Co ; 18,19 Pt-Co. Sampel air gambut KLP 3 belum dapat dikatakan layak untuk digunakan sebagai sumber air bersih dengan tingkat kekeruhan dan intensitas warna masing-masing adalah 26,29 NTU dan 49,78 Pt-Co.
\end{abstract}

Kata kunci : Air gambut, kitosan, jamur lapuk putih, koagulasi, flokulasi 


\title{
THE UTILIZATION OF CHITOSAN AND WHITE ROT FUNGUS (Trametes versicolor) FOR REDUCING THE COLOUR AND TURBIDITY OF PEAT WATER AS AN ALTERNATIVE SOURCE OF WATER SUPPLY
}

\begin{abstract}
This research was conducted with the goal of finding the optimum dosage ratio of chitosan and white rot fungus (trametes versicolor) and studying optimum process conditions that influence coagulation and flocculation, settling time and slow time stirring to the reduction of water turbidity and color of the peat. Determination of the optimum dose performed with various dose of chitosan and white rot fungus ratio 800: 200; 600: 400; 400: 600; 500: 500 and 200: 800 (mg / L water peat). Effect of the effectiveness of coagulation and flocculation studied by means of coagulation performed with various stirring time 5, 10, 15, 20 and 25 minutes. Effect of settling time studied with suspended the coagulation suspensions results at 15, 30, 45, 60 and 90 minutes. The optimum dose and conditions subsequent coagulation and flocculation applied to 3 (three) different peat water samples.

Comparison of the optimum dose ratio of chitosan and white rot fungus for turbidity parameter is 600: $400 \mathrm{mg} / \mathrm{L}$ water peat with effectiveness of $95.06 \%$, and for of color parameters optimum dose ratio was 400: $600 \mathrm{mg} / \mathrm{L}$ water peat with $96.20 \%$ effectiveness. The optimum slow stirring time was 10 minutes for parameters turbidity and color of peat water, with the effectiveness $96.34 \%$ and $96.68 \%$ respectively. The optimum suspended time was 45 minutes for the parameters of turbidity and 60 minutes for color parameters of peat water, with the effectiveness $96.37 \%$ and $96.68 \%$ respectively. Application of chitosan and white rot fungus on peat water samples, KLP 1 and KLP 2 can be used as source of clean water, with turbidity levels and color intensity was 1.27 NTU; 2.90 NTU and 6.30 Pt-co; 18.19 pt-co. Peat water samples KLP 3 can not be feasible for use as a source of clean water with turbidity levels and the intensity of each color was 26.29 and 49.78 NTU Pt-Co
\end{abstract}

Keywords: Water peat, chitosan, white rot fungus, coagulation, flocculation

\section{PENDAHULUAN}

Pada dasarnya air gambut adalah air permukaan yang banyak terdapat di daerah berawa atau dataran rendah yang mempunyai ciri-ciri umum yaitu intensitas warna tinggi (kuning atau merah kecoklatan) yang disebabkan oleh bahan-bahan humus dalam air tersebut. Tingginya kandungan besi $(\mathrm{Fe})$ pada air gambut pada dasarnya bukanlah disebabkan karena pencemaran tetapi cenderung kepada kondisi alamiah lahan gambut dengan kandungan senyawa besi yang tinggi, seperti senyawa pirit (FeS) yang akan terlarut dalam bentuk ion logam $\mathrm{Fe}$ terutama pada saat kondisi badan sangat asam (pH 2-4) (Pahlevi, 2009).

Tujuan pengolahan air adalah untuk menghilangkan bahan pengotor yang ada di dalam air dan secara efisien dapat berfungsi untuk memproduksi air jernih yang tidak berasa, tidak berbau, aman dan menyegarkan. Salah satu langkah penting dalam pengolahan air adalah penghilangan kekeruhan dan warna air (Alaerts, 1987). Salah satu prinsip yang digunakan dalam pengolahan air secara kimia adalah menambahkan bahan kimia (koagulan) kitosan yang dapat mengikat bahan pencemar yang dikandung air limbah, 
kemudian memisahkan (mengendapkan atau mengapungkan) pada umumnya bahan seperti aluminium sulfat (tawas), fero sulfat, kitosan, foli ammonium klorida atau poli elektrolit organik dapat digunakan sebagai koagulan. Sistem koagulasi dengan system hidrolis merupakan cara yang relatif ekonomis karena tidak memerlukan tambahan power listrik seperti sistem mekanis.

Salah satu metode yang dikembangkan metode pengolahan air dengan menggunakan jamur, dapat diharapkan terwujudnya proses pengolahan air yang eco-friendly. Pengolahan air dengan menggunakan koagulan jamur lapuk putih dapat dilakukan dengan cara merendamkan jamur lapuk putih ke dalam limbah mendapatkan hasil yang optimal. (Kandelbauer and Guebitz, 2007). Jamur lapuk putih juga dapat menghilangkan warna dalam suatu media, dengan cara tidak meningkatkan kadar racun dalam media tersebut (Ramsay and Goodde. 2004). Selain dengan menggunakan metode di atas, kekeruhan juga dapat dihilangkan melalui pebubuhan sejenis bahan kimia dengan sifat-sifat tertentu yang disebut koagulan/flokulan. Umumnya koagulan tersebut adalah tawas, namun dapat pula garam Fe(III) atau salah satu polielektrolit organik seperti kitosan. Selain pembubuhan koagulan/flokulan diperlukan pengadukan sampai flok-flok terbentuk. Flok-flok ini mengumpulkan partikelpartikel kecil dan koloid tersebut (bertumbukan) dan akhirnya bersamasama mengendap (Alaerts, 1987).

Berhubungan dengan sifatnya
sebagai adsorben, ketika kitosan
dilarutkan dalam larutan asam seperti
asam asetat, format dan glutamat gugus
amina primer pada kitosan akan
terprotonasi dan bermuatan positif. Oleh
karena itu molekul kitosan yang
tersolvasi merupakan polikationik yang dapat terkoagulasi jika ditambahkan partikel atau molekul yang bermuatan negatif seperti sodium alginate, anion sulfat san fosfat (Kaban, 2009).

Salah satu caranya yang direkomendasikan adalah dengan mengkoagulasi senyawa organik penyebab warna dan kekeruhan yang ada dalam air tersebut untuk kemudian disisihkan lewat proses pengendapan dan penyaringan. Koagulan yang akan digunakan dalam hal ini adalah campuran kitosan dan jamur lapuk putih yang samasama memiliki kemampuan sebagai polikationik, sehingga dengan mencampurkan kedua bahan tersebut dapat memberikan hasil yang lebih baik dalam hal menurunkan warna dan kekeruhan air gambut yang akan digunakan sebagai alternatif sumber air bersih.

\section{METODE PENELITIAN}

\section{Alat dan Bahan Penelitian}

\section{Alat Penelitian}

Peralatan yang digunakan pada penelitian ini antara lain, penangas listrik (hot plate), pengaduk magnetik (magnetic stirrer), neraca analitik, ayakan 140 mesh, blender, kertas saring, kertas $\mathrm{pH}$ universal, seperangkat alat gelas, peralatan sampling air, wadah sampel air, Turbidimeter, Lovi Bond, stop watch dan oven.

\section{Bahan Penelitian}

Bahan-bahan yang digunakan pada penelitian ini antara lain kulit dan kepala udang (Panaeus monodon), jamur lapuk putih, minyak goreng, akuades, $\mathrm{NaOH}, \mathrm{HCl}$ pekat, asam cuka perdagangan, asam nitrat encer $\left(\mathrm{HNO}_{3}\right.$ $0,01 \mathrm{M}$ ), air gambut pedalaman.

\section{Prosedur Penelitian}




\section{Isolasi Kitosan dan Preparasi Jamur Lapuk Putih}

Isolasi kitosan dilakukan melalui beberapa tahapan yaitu : deproteinasi, demineralisasi dan deasetilasi. Pembuatan koagulan jamur lapuk putih dilakukan dengan cara, jamur yang sudah diambil dibersihkan terlebih dahulu untuk menghilangkan kotoran, kemudian dijemur sampai kering setelah itu ditumbuk sampai halus kemudian diayak dengan ayakan 140 mesh. Serbuk tepung halus yang dihasilkan langsung dapat digunakan sebagai koagulan.

\section{Penentuan Perbandingan Dosis Optimum Kitosan dan Jamur Lapuk Putih}

Penentuan perbandingan dosis optimum kitosan dan jamur lapuk putih dilakukan dengan cara, sejumlah kitosan dan jamur lapuk putih dengan perbandingan $800: 200 ; 600: 400 ; 400$ : $600 ; 500: 500$ dan $200: 800(\mathrm{mg} / \mathrm{L}$ air gambut) dimasukkan ke dalam gelas kimia dan masing-masing ditambahkan dengan $100 \mathrm{~mL}$ air gambut. Campuran diaduk dengan kecepatan 100 rpm dengan bantuan pengaduk magnetik selama 3 menit, lalu diikuti dengan pengadukan $40 \mathrm{rpm}$ selama 15 menit untuk kemudian diendapkan selama 60 menit, campuran disaring dan dianalisis.

\section{Pengaruh Variasi Waktu Pengadukan Dengan Kecepatan $40 \mathrm{Rpm}$ pada Proses Koagulasi dan Flokulasi Terhadap Penurunan Kekeruhan dan Warna pada Air Gambut}

Pengaruh variasi waktu pengadukan pada proses koagulasi terhadap penurunan kekeruhan dan warna pada air gambut dipelajari dengan sejumlah kitosan dan jamur lapuk putih dengan perbandingan dosis optimum dimasukkan ke dalam 5 (lima) gelas kimia dan masing-masing ditambahkan dengan $100 \mathrm{~mL}$ air gambut. Campuran diaduk dengan kecepatan 100 rpm dengan bantuan pengaduk magnetik selama 3 menit lalu diikuti dengan pengadukan $40 \mathrm{rpm}$ dengan waktu pengadukan divariasikan selama 5, 10 , 15, 20 dan 25 menit dimulai tepat setelah pengadukan cepat selesai, kemudian diendapkan selama 60 menit, campuran disaring dan dianalisis

\section{Pengaruh Variasi Waktu Pengendapan Pada Proses Koagulasi dan Flokulasi Terhadap Penurunan Kekeruhan dan Warna pada Air Gambut}

Pengaruh variasi waktu pengendapan pada proses flokulasi terhadap penurunan kekeruhan dan warna pada air gambut dipelajari dengan cara sejumlah kitosan dan jamur lapuk putih dengan perbandingan dosis optimum dimasukkan ke dalam 5 (lima) gelas kimia dan masing-masing ditambahkan dengan $100 \mathrm{~mL}$ air gambut. Campuran diaduk dengan kecepatan 100 rpm dengan bantuan pengaduk magnetik selama 3 menit lalu diikuti dengan pengadukan dengan kecepatan $40 \mathrm{rpm}$ dengan waktu pengadukan optimum, kemudian diendapkan dengan waktu bervariasi selama 15, 30, 45, 60 dan 90 menit, campuran disaring dan dianalisis.

\section{Aplikasi Kitosan dan Jamur Lapuk Putih Untuk Menurunkan Kekeruhan dan Warna pada Air Gambut}

Aplikasi kitosan dan jamur lapuk putih untuk menurunkan kekeruhan dan warna pada air gambut dilakukan pada 3 (tiga) sampel air gambut yang diperoleh dari 3 (tiga) lokasi yang berbeda. Sejumlah tertentu kitosan dan jamur lapuk sesuai dengan perbandingan dosis optimum ditambahkan ke dalam $100 \mathrm{~mL}$ air gambut, proses koagulasi dan flokulasi dilakukan pada waktu pengadukan dan waktu pengendapan optimum untuk masing-masing sampel air gambut. Campuran yang dihasilkan 
dipisahkan dengan cara dekantir dan penyaringan untuk kemudian dilakukan pengukuran kadar kekeruhan dan warna terhadap filtrat yang diperoleh.

\section{HASIL DAN PEMBAHASAN}

\section{Penentuan Perbandingan Dosis Optimum Kitosan dan Jamur Lapuk Putih}

Efektifitas koagulasi dalam menurunkan warna dan kekeruhan air gambut dinyatakan sebagai persen penyisihan warna dan turbiditas (kekeruhan) akibat proses koagulasi. Efektifitas koagulasi berdasarkan warna dan kekeruhan dihitung dengan persamaan berikut :

Efektifitas Koagulasi warna

$$
=\frac{\text { Warna }_{S_{0}}-\text { Warna }_{S K}}{\text { Warna }_{S o}} \times 100 \%
$$

Efektifitas Koagulasi kekeruhan

$$
=\frac{\text { Turbiditas }_{S o}-\text { Turbiditas }_{S K}}{\text { Turbiditas }_{S o}} \times 100 \%
$$

dimana, Warnaso dan Turbiditas So $_{\text {Sodah }}$ warna dan turbiditas air gambut umpan sebelum koagulasi dan Warnaso dan
Turbiditas $_{\text {So }}$ adalah warna dan turbiditas air gambut umpan setelah mengalami koagulasi.

Perbandingan dosis kitosan dan jamur lapuk akan menentukan seberapa besar kekeruhan dan warna yang mampu tersisihkan secara optimal oleh kitosan dan jamur lapuk putih. Pada Gambar 1 dan 2 disajikan bagaimana pengaruh variasi perbandingan dosis kitosan dan jamur lapuk putih yang digunakan terhadap besarnya kekeruhan dan warna air gambut yang tersisihkan karena proses koagulasi dan flokulasi oleh kitosan dan jamur lapuk putih.

Berdasarkan Gambar 1 dosis kitosan dan jamur lapuk putih dengan perbandingan $600: 400 \mathrm{mg} / \mathrm{L}$ air gambut merupakan dosis optimum koagulasi untuk menurunkan turbiditas (kekeruhan) pada air gambut dengan efektifitas sebesar 95,06\%. Sedangkan untuk parameter warna, dosis kitosan dan jamur lapuk putih sebagai dosis optimum koagulasi yang dapat menurunkan warna air gambut secara optimal adalah dengan perbandingan $400: 600 \mathrm{mg} / \mathrm{L}$ air gambut dengan efektivitas $96,20 \%$.

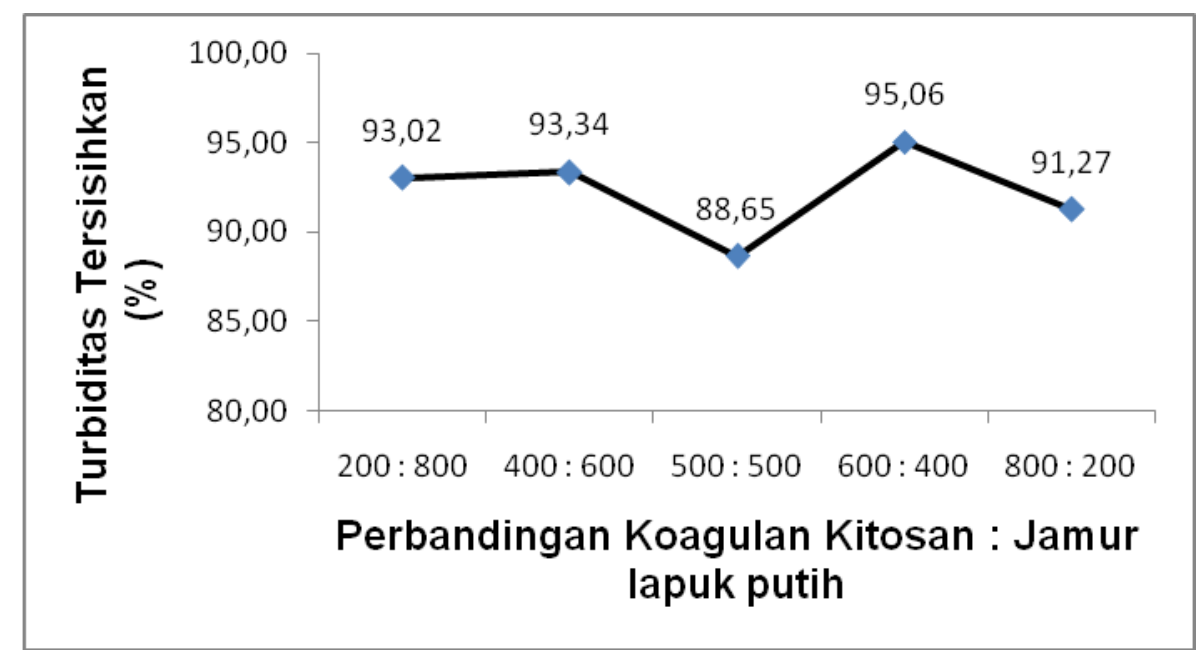

Gambar 1. Pengaruh Perbandingan Dosis Kitosan dan Jamur Lapuk Putih terhadap Turbiditas Tersisihkan 


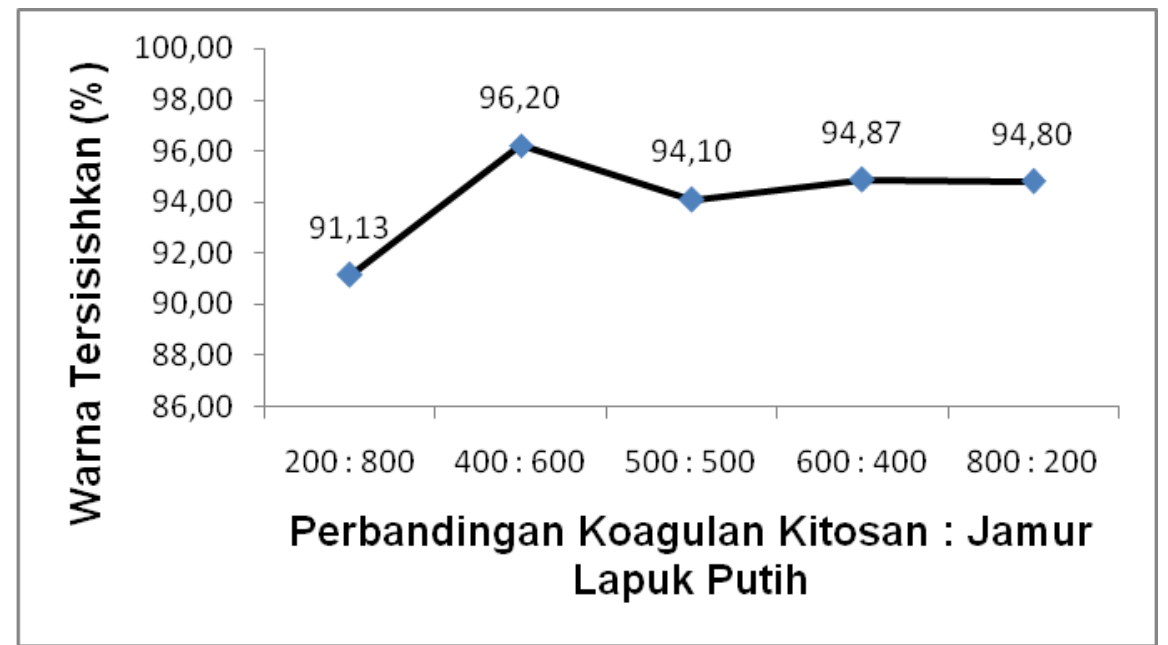

Gambar 2. Pengaruh Perbandingan Dosis Kitosan dan Jamur Lapuk Putih terhadap Warna Tersisihkan

Penurunan turbiditas (kekeruhan) dengan proses koagulasi dan flokulasi ini dengan efektifitas terbesar pada dosis kitosan dan jamur lapuk dengan perbandingan $600: 400 \mathrm{mg} / \mathrm{L}$ air gambut. Perbandingan tersebut menunjukkan bahwa komposisi kitosan lebih banyak dibandingkan jamur lapuk putih sebagai koagulan artinya kitosan yang lebih memegang perananan untuk menurunkan turbiditas (kekeruhan) pada air gambut. Turbiditas dikatakan menurun apabila bahan - bahan kasar dalam air gambut telah berkurang karena turbiditas merupakan suatu ukuran yang menyatakan sampai beberapa cahaya mampu menembus air, dimana cahaya menembus air akan mengalami pemantulan oleh bahan - bahan tersuspensi dan bahan koloidal. Berdasarkan sifat kitosan yang diklasifikasikan sebagai polielektrolit kationik maka kitosan dapat bertindak sebagai koagulan yang dapat menstabilkan partikel-patikel koloid dalam air gambut pada proses koagulasi untuk memfasilitasi pertumbuhan partikel selama flokulasi yaitu ketika terjadi kontak diantara partikel-partikel koloid yang telah mengalami destabilisasi sehingga ukuran partikel-partikel nya tumbuh menjadi partikel yang lebih besar. (Kiely, 1998). Efektifitas kitosan dalam menurunkan kekeruhan air gambut tersebut juga didukung oleh keberadaan jamur lapuk putih yang mengandung enzim yang bekerja menurunkan kekeruhan dengan cara menyerap dan menggumpalkan sehingga terbentuk gumpalan (flok) secara simultan dengan kitosan sehingga proses koagulasi dan flokulasi terjadi secara optimal.

Pada parameter warna penambahan kitosan dan jamur lapuk putih dengan perbandingan $400: 600 \mathrm{mg} / \mathrm{L}$ air gambut memberikan efektifitas terbesar dibandingkan perbandingan dosis lain. Perbandingan tersebut menunjukkan bahwa pada parameter warna komposisi jamur lapuk putih lebih banyak dibandingkan kitosan sebagai koagulan artinya jamur lapuk putih yang lebih memegang perananan untuk menurunkan warna pada air gambut. Jamur lapuk putih memproduksi enzim-enzim pendegradasi lignin yang nonspesifik yang dapat mendegradasi berbagai jenis zat pengotor organik terlarut, termasuk warna pada air gambut. Enzim-enzim yang diproduksi oleh jamur menguraikan zat pembentuk warna dalam air gambut dalam hal ini senyawa organik terlarut seperti asam humus yang terdiri dari 
asam humat, asam fulfat dan humin dapat direduksi secara efektif menjadi komponen yang tidak berbahaya. Proses koagulasi untuk menurunkan kadar warna pada air gambut ini selain kemampuan jamur lapuk putih dalam mendegradasi senyawa organik penghasil warna air gambut, juga dibantu dengan keberadaan kitosan yang selain dapat bertindak sebagai koagulan juga dapat berfungsi sebagai adsorben yang dapat mengikat ion-ion logam terlarut dalam air gambut seperti Fe dan Mn secara sinergis sehingga proses koagulasi untuk menurunkan kadar warna pada air gambut dapat berjalan secara optimal.

\section{Pengaruh Variasi Waktu Pengadukan Dengan Kecepatan 40 rpm pada Proses Koagulasi dan Flokulasi Terhadap Penurunan Kekeruhan dan Warna Pada Air Gambut}

Pada bagian ini akan ditinjau pengaruh variasi waktu pengadukan dengan kecepatan $40 \mathrm{rpm}$ koagulan terhadap efektifitas koagulasi, yang dinyatakan sebagai persentase (\%) penyisihan berdasarkan parameter turbiditas (kekeruhan) dan warna pada tiap variasi waktu. Persentase efektifitas koagulasi untuk tiap variasi waktu pengadukan dengan kecepatan $40 \mathrm{rpm}$ koagulan ditunjukkan Gambar 4 dan 5.

Berdasarkan Gambar 4 dan 5 dapat dilihat bahwa persentase efektifitas koagulasi terhadap pemisahan kekeruhan dan warana memiliki kecenderungan naik jika waktu pengadukan dinaikkan dari 5 menit menjadi 10 menit dan kemudian terus turun setiap 5 menit penambahan waktu pengadukan dari 10 menit hingga 25 menit. Koagulasi, dengan penambahan koagulan kitosan dan jamur lapuk putih akan menghasilkan reaksi kimia dimana muatan-muatan negatif yang saling tolak menolak di sekitar partikel terlarut berukuran koloid akan ternetralisasi oleh ion-ion positif dari koagulan dan akhirnya partikel-partikel koloid akan saling menarik dan menggumpal membentuk flok.

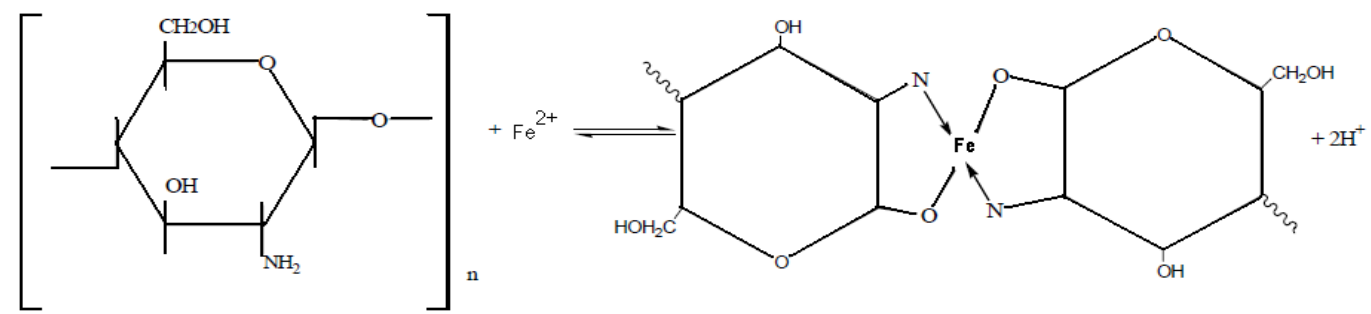

Gambar 3. Pengikatan Ion Logam Fe oleh Kitosan (Schmuhl et al. (2001).

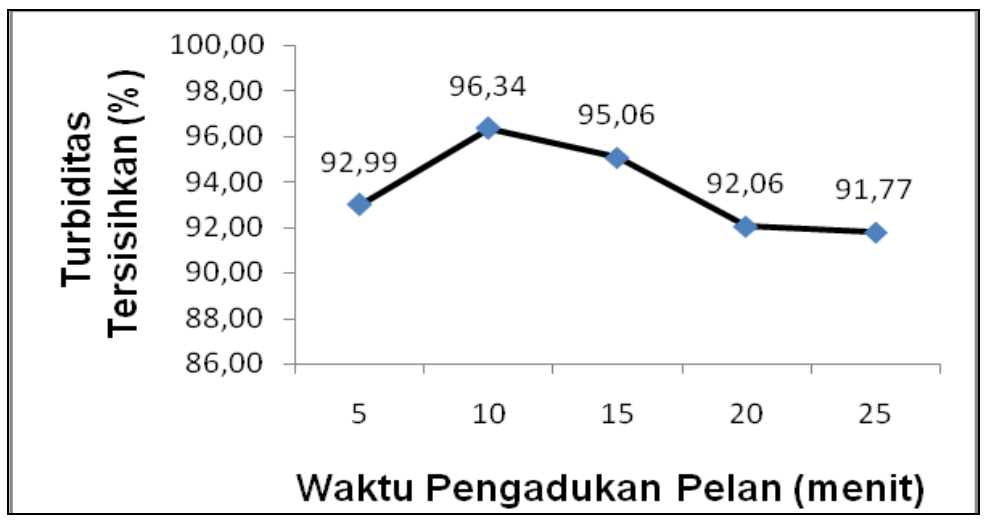

Gambar 4. Pengaruh Waktu Pengadukan dengan kecepatan 40 rpm terhadapTurbiditas Tersisihkan 


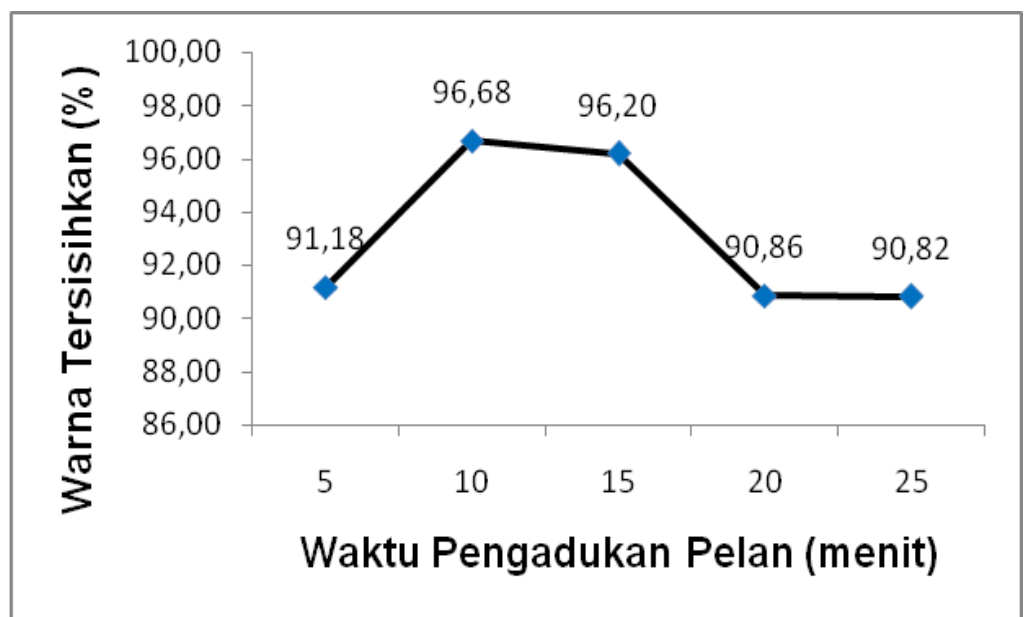

Gambar 5. Pengaruh Waktu Pengadukan dengan kecepatan 40 rpm terhadapWarna Tersisihkan

Pengadukan dengan kecepatan 40 rpm akan memperpendek jarak antar partikel sehingga gaya tarik- menarik antar partikel menjadi lebih besar dan dominan dibandingkan gaya tolaknya, yang menghasilkan kontak dan tumbukan antar partikel yang lebih banyak dan lebih sering. Kontak inilah yang menggumpalkan partikel-partikel padat terlarut terkoagulasi berukuran mikro menjadi partikel-partikel flok yang lebih besar. Flok-flok ini kemudian akan beragregasi. Ketika pertumbuhan flok sudah cukup maksimal (massa, ukuran), flok-flok ini akan mengendap ke dasar karena pengaruh gaya gravitasi, sehingga terbentuk dua lapisan, yaitu lapisan air jernih pada bagian atas dan lapisan endapan flok yang menyerupai lumpur pada dasar reservoir.

Pada waktu pengadukan 20 menit, terjadi penurunan persentase efektifitas koagulasi yang lebih besar dibandingkan pada waktu lainnya. Hal ini disebabkan pada waktu pengadukan 20 menit inilah flok-flok bahan organik air gambut yang telah terbentuk sebelumnya pecah dengan hebatnya. Fenomena ini memungkinkan hampir seluruh flok bahan organik air gambut yang terbentuk terurai kembali menjadi partikel organik tunggal, sehingga dihasilkan air gambut setelah koagulasi yang paling keruh dengan intensitas warna yang kembali mencolok dibandingkan dengan yang dihasilkan dengan waktu-waktu pengadukan lainnya, yang menandakan terkonsentrasinya partikel organik air gambut dalam jumlah besar.

\section{Pengaruh Variasi Waktu Pengendapan pada Proses Koagulasi dan Flokulasi Terhadap Penurunan Kekeruhan dan Warna pada Air Gambut}

Berdasarkan data pencobaan pengaruh waktu pengendapan terhadap turbiditas (kekeruhan) dan warna tersisihkan dari air gambut pada proses koagulasi dan flokulasi terlihat bahwa waktu pengendapan berpengaruh nyata terhadap penurunan turbiditas dan warna air gambut sebagaimana terlihat pada Gambar 6 dan 7.

Pada parameter kekeruhan waktu pengendapan 45 menit sampai dengan 90 menit memperlihatkan bahwa penurunan kekeruhan air gambut sudah mulai konstan masing-masing efektifitas untuk 45 menit adalah 96,37\%, 60 menit adalah 96,34\%, dan 90 menit adalah 95,89\%. Penurunan turbiditas air gambut ini disebabkan adanya penambahan ukuran, perubahan bentuk dan penambahan densitas dari partikel-partikel tersuspensi, 
akibatnya gaya gravitasi yang bekerja pada flok- flok lebih besar dari pada gaya penahan air gambut hingga flok - flok mengalami percepatan turun kearah dasar (mengendap) proses ini akan berhenti setelah semua flok yang terbentuk telah habis terendapkan.

Pada parameter warna waktu pengendapan 60 menit dan 90 menit memperlihatkan bahwa penurunan intensitas warna air gambut sudah mulai konstan masing-masing efektifitas untuk 60 menit adalah 96,68\%, dan 90 menit adalah $95,76 \%$. Penurunan intensitas warna ini disebabkan karena selama proses koagulasi enzim-enzim lignolitik yang terdapat pada jamur lapuk putih berperan dalam mendegradasi senyawasenyawa organik terlarut yang menghasilkan warna dalam air gambut, yang diduga adalah senyawa humin.
Proses koagulasi dan flokulasi kemudian dibantu dengan keberadaan kitosan yang bekerja pada proses pembentukan flokflok dari hasil degradasi senyawa humin.

Pada waktu pengendapan yang optimal akan terjadi penambahan ukuran, perubahan bentuk dan penambahan densitas dari partikel-partikel terususpensi, akibatnya gaya gravitasi yang bekerja pada flok- flok lebih besar dari pada gaya penahan air gambut hingga flok - flok mengalami percepatan turun kearah dasar (mengendap) proses ini akan berhenti setelah semua flok yang terbentuk telah habis terendapkan. Pada proses netralisasi dan adsorpsi partikel warna yang terjadi menyebabkan partikel koloid yang sudah mengendap akan berbalik menjadi stabil kembali akibatnya flok tidak terbentuk dengan baik (Eckenfelder, 1989).

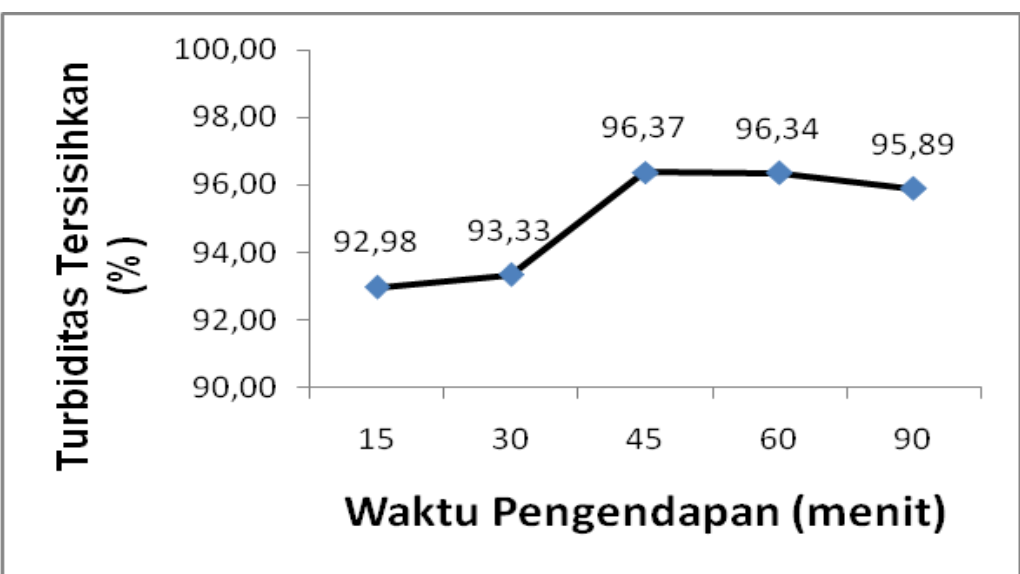

Gambar 6. Pengaruh Waktu Pengendapan terhadapTurbiditas Tersisihkan

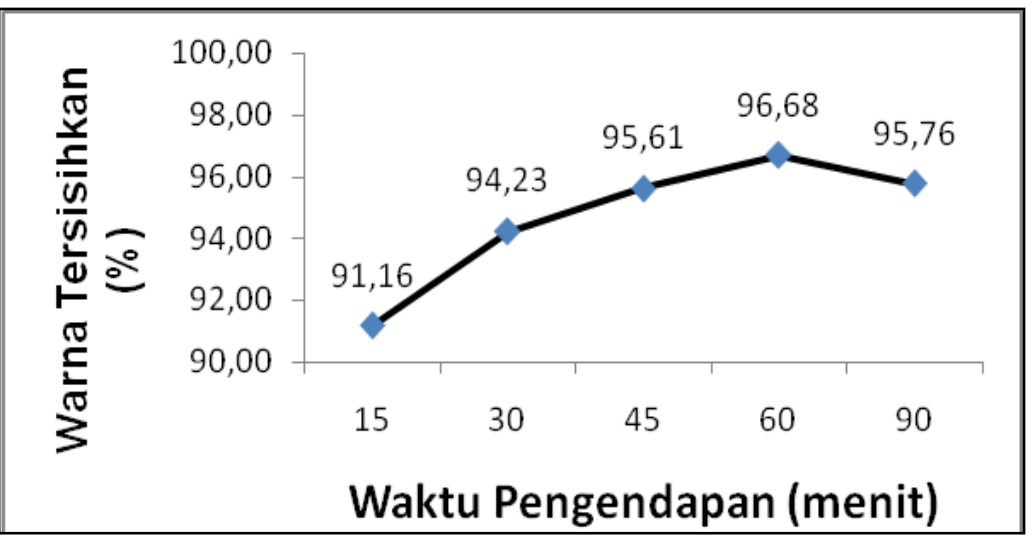

Gambar 7. Pengaruh Waktu Pengendapan terhadapWarna Tersisihkan 


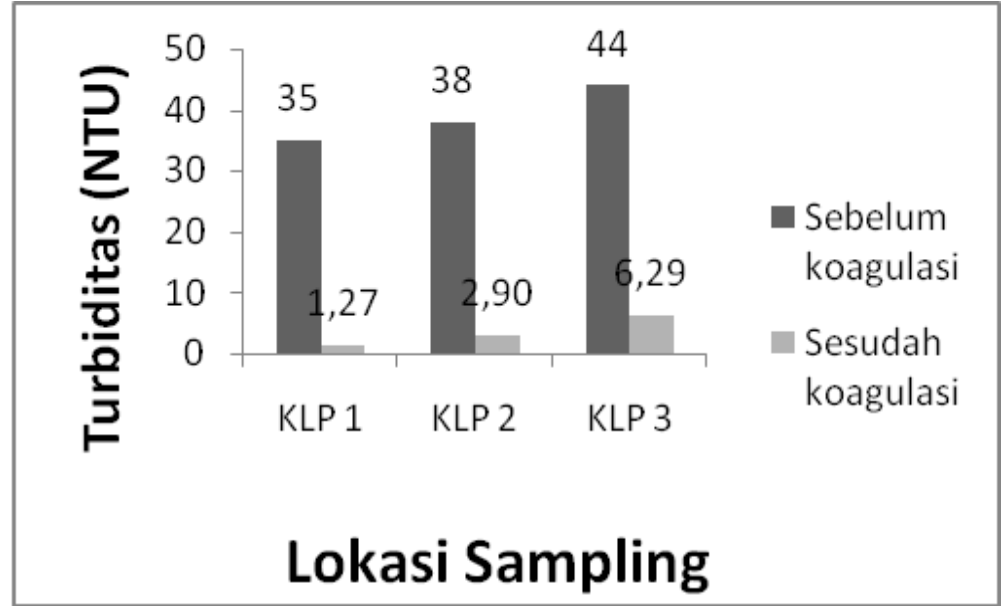

Gambar 8. Pengaruh Aplikasi Kitosan dan Jamur Lapuk Putih terhadap Parameter Kekeruhan Pada Sampel Air Gambut Kalampangan

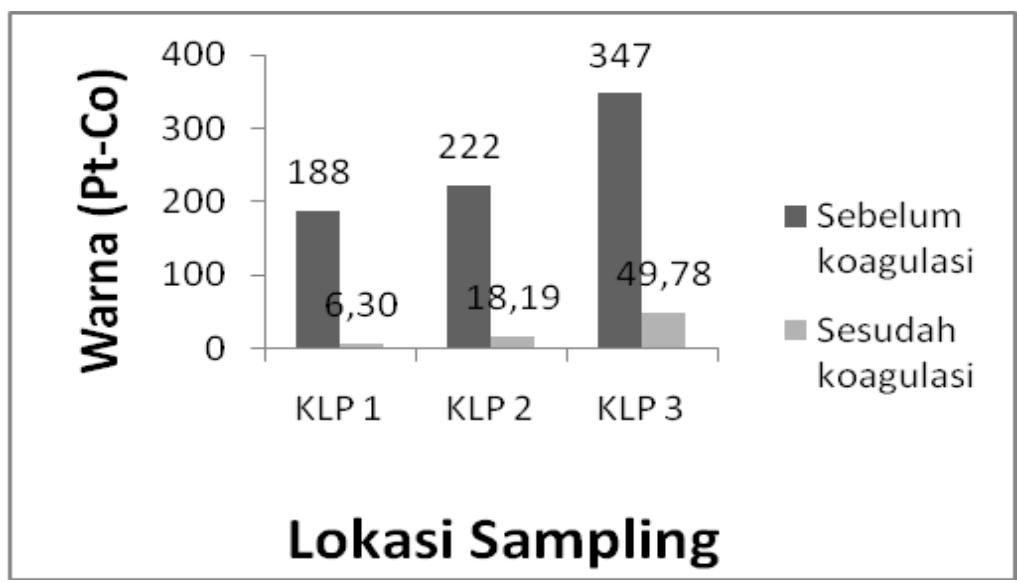

Gambar 9. Pengaruh Aplikasi Kitosan dan Jamur Lapuk Putih terhadap Parameter Warna Pada Sampel Air Gambut Kalampangan

Aplikasi Kitosan dan Jamur Lapuk Putih untuk Menurunkan Kekeruhan dan Warna pada Air Gambut

Aplikasi kitosan dan jamur lapuk putih untuk menurunkan kekeruhan dan warna pada air gambut dilakukan pada 3 (tiga) sampel air gambut yang diperoleh dari 3 (tiga) lokasi yang berbeda. Pada Gambar 8 dan 9 disajikan bagaimana hasil aplikasi kitosan dan jamur lapuk putih pada 3 (tiga) sampel air gambut dengan lokasi berbeda.

Kemampuan kitosan dan jamur lapuk putih dalam mereduksi kekeruhan dan warna pada sampel air gambut akan sangat dipengaruhi oleh tingkat kekeruhan dan intensitas warna awal pada masing-masing sampel air gambut. Semakin tinggi tingkat kekeruhan dan intensitas warna awal pada sampel air gambut maka akan mengurangi kemampuan (kapasitas) kitosan dan jamur lapuk putih sebagai koagulan. Pada kitosan yang merupakan koagulan yang bersifat polikationik, tingkat kekeruhan dan intensitas warna awal yang tinggi pada sampel KLP 2 dan KLP 3 mengakibatkan muatan positif yang ada pada kitosan menjadi kurang berarti untuk menetralkan muatan negatif yang saling tolak-menolak disekitar partikelpartikel bahan organik terlarut yang ada pada air gambut, sehingga akan sukar 
menyebabkan terjadinya gaya tarikmenarik antar partikel koloid untuk membentuk flok-flok bermutan netral. Keadaan tersebut menyebabkan kitosan tidak dapat bertindak sebagai koagulan secara optimal. Intensitas warna yang sangat tinggi pada sampel air gambut KLP 2 dan KLP 3 menunjukkan banyaknya senyawa organik terlarut yang terkandung di dalamnya sehingga keberadaan enzim lignolitik pada jamur lapuk tidak dapat mendegradasi semua senyawa organik terlarut dalam air gambut secara optimal.

Berdasarkan persyaratan kualitas air minum menurut Keputusan Menteri Kesehatan RI. No. 492/MenKes/PER/IV/2010, baku mutu untuk warna dan kekeruhan masingmasing parameter adalah kekeruhan 5 NTU, dan zat warna 15 Pt-Co. Berdasarkan baku mutu tersebut selanjutnya dapat dibandingkan dengan tingkat kekeruhan dan intensitas warna air gambut hasil koagulasi yang masih terdapat dalam air gambut. Berdasarkan Gambar 8 dan 9 terlihat bahwa setelah koagulasi dengan menggunakan kitosan dan jamur lapuk putih tingkat kekeruhan yang tersisa pada masing-masing sampel air gambut KLP 1, KLP 2 dan KLP 3 berturut-turut adalah air gambut adalah 1,27 NTU; 2,90 NTU dan 6,29 NTU, sedangkan intensitas warna berturut-turut adalah 6,30 Pt-Co; 18,19 Pt-Co dan 49,78 Pt-Co Jika dibandingkan dengan baku mutu di atas dengan keadaan tersebut maka sampel gambut KLP 1 dan KLP 2 sudah dapat dikatakan layak untuk digunakan sebagai sumber air bersih jika ditinjau dari parameter kekeruhan dan warna dalam air gambut. Sedangkan sampel air gambut KLP 3 belum dapat dikatakan layak digunakan sebagai sumber air bersih jika ditinjau dari parameter kekeruhan dan warna dalam air gambut, akan tetapi sampel air gambut tersebut mungkin dapat digunakan untuk keperluan lain, misalnya pada bidang perikanan dan pertanian. Konsentrasi pada baku mutu tersebut belum dapat tercapai pada sampel air gambut KLP 3 diduga karena tingkat kekeruhan dan intensitas warna pada sampel air gambut tersebut cukup besar yaitu masingmasing 6,29 NTU dan 49,78 Pt-Co , sehingga setelah koagulasi kitosan dan jamur lapuk putih yang digunakan belum dapat mereduksi kekeruhan dan warna air gambut sampai di bawah baku mutu.

\section{KESIMPULAN}

Berdasarkan hasil penelitian yang dilakukan dapat disimpulkan bahwa :

1. perbandingan dosis optimum kitosan dan jamur lapuk putih pada parameter kekeruhan adalah 600 : $400 \mathrm{mg} / \mathrm{L}$ air gambut dengan efektifitas sebesar 95,06\%, dan untuk parameter warna dengan perbandingan dosis optimum 400 : $600 \mathrm{mg} / \mathrm{L}$ air gambut dengan efektifitas $96,20 \%$.

2. Waktu pengadukan dengan kecepatan 40 rpm yang menunjukkan hasil koagulasi yang optimal yaitu 10 menit untuk parameter kekeruhan dan warna air gambut, dengan efektifitas masing-masing adalah $96,34 \%$ dan $96,68 \%$.

3. Waktu pengendapan yang menunjukkan hasil koagulasi yang optimal yaitu 45 menit untuk parameter kekeruhan dan 60 menit untuk parameter warna air gambut, dengan efektifitas masing-masing adalah $96,37 \%$ dan $96,68 \%$.

4. Pada aplikasi kitosan dan jamur lapuk putih pada air gambut, setelah koagulasi dan flokulasi sampel air gambut KLP 1 dan KLP 2 dapat dikatakan layak untuk digunakan sebagai sumber air bersih jika ditinjau dari parameter kekeruhan dan warna air gambut dengan tingkat 
kekeruhan dan intensitas warna masing-masing adalah 1,27 NTU ; 2,90 NTU dan 6,30 Pt-Co ; 18,19 PtCo. Sedangkan sampel air gambut KLP 3 belum dapat dikatakan layak untuk digunakan sebagai sumber air bersih dengan tingkat kekeruhan dan intensitas warna masing-masing adalah 26,29 NTU dan 49,78 Pt-Co.

\section{SARAN}

Saran-saran yang diajukan untuk kelanjutan penelitian ini yaitu perlu dipelajari pengaruh $\mathrm{pH}$ campuran terhadap efektifitas koagulasi karena $\mathrm{pH}$ berperan dalam terbentuknya muatan positif pada koagulan. Perlu dipelajari perlakuan lain (aktivasi biomassa) dengan pengasaman menggunakan $\mathrm{HCl}$ atau $\mathrm{HNO}_{3}$ terhadap koagulan jamur lapuk putih sehingga lebih meningkatkan kemampuannya dalam menurunkan kekeruhan dan warna air gambut. Perlu dipelajari kombinasi kitosan dengan bahan lain seperti kulit pisang Kepok sebagai koagulan untuk menurunkan kekeruhan dan warna air gambut yang akan digunakan sebagai sumber air bersih.

\section{DAFTAR PUSTAKA}

Alaerts, G. 1987, Metoda Penelitian Air. Surabaya, Usaha Nasional.

Eckenfelder, W.W., 1989, Industrial Water Pollution Control. $2^{\text {nd }} e d$, Mc Graw-Hill Inc,New York
Kaban, Jamaran. 2009. Modifikasi Kimia dari Kitosan dan Aplikasi Produk yang dihasilkan. Medan. Universitas Sumatera Utara.

Kandelbauer and Guebitz, 2007, Trametes versicolor Growth and Laccase Induction with ByProducts of Pulp and Paper Industry, Pontifisia Universidat Catolica de Valparaiso-Chile.

Keputusan Menteri Kesehatan RI. No. 492/MenKes/PER/IV/2010.

Lampiran II, Tentang Kualitas Air Minum.

Pahlevi, M.R., 2009, Analisis Kadar (Fe) dan Mangan Dari Air Gambut Setelah Dijernihkan Dengan Penambahan Tulang Ayam. Medan, Pascasarjana Universitas Sumatera Utara (USU).

Ramsay, J and Goodde, C. 2004. Biodegradasio of Wheat Straw by Trametes versicolor, Pontifisia Universidat Catolica de Valparaiso-Chile.

Schmuhl, HM Krieg dan K Keizer, 2001, Adsortion of $\mathrm{Cu}$ (II) and $\mathrm{Cr}$ (II) ions by Chitosan : Kinetics and Equilibrium Studies, University for Christian Higher Education, South Africa, vol.27 No. 1 January 2001. 